European journal of American studies

\title{
'Smooth' and 'Alternative' Patriotisms: Chicago and the decline of a civil rights strategy
}

\section{Sam Hitchmough}

\section{(2) OpenEdition}

\section{Journals}

Electronic version

URL: https://journals.openedition.org/ejas/12210

DOI: $10.4000 /$ ejas. 12210

ISSN: 1991-9336

Publisher

European Association for American Studies

Electronic reference

Sam Hitchmough, "'Smooth' and 'Alternative' Patriotisms: Chicago and the decline of a civil rights strategy", European journal of American studies [Online], 12-2 | 2017, Online since 01 August 2017. connection on 09 July 2021. URL: http://journals.openedition.org/ejas/12210 ; DOI: https://doi.org/ 10.4000/ejas. 12210

This text was automatically generated on 9 July 2021.

Creative Commons License 


\title{
'Smooth' and 'Alternative' Patriotisms: Chicago and the decline of a civil rights strategy
}

\author{
Sam Hitchmough
}

1 At the Riverside Church in New York, April 1967, Martin Luther King, Jr. did not just speak out against the war in Vietnam, he was in many ways defending one of the underlying ideological strategies of the entire civil rights movement. He urged people to avoid confusing dissent with disloyalty, stressed that he voiced his opinion to save the soul of America, and cautioned against what he called "smooth patriotism". ${ }^{i}$

2 This article forwards and explores the idea that a significant ideological characteristic of the civil rights movement was the concept and use of an 'alternative patriotism.' After exploring its value as a lens through which to view King and the movement, and the 'smooth' patriotism that they were pitted against, the article discusses how the open-housing campaign in Chicago witnessed a fundamental shift in how the strategy was utilised. This represented a broader concern in social and human rights, and helps an understanding of the move toward a more 'militant' position from 1966 onwards.

\section{Alternative patriotism up to the 'wall' of Chicago}

Alternative patriotism embodied what King considered to have been a truer, higher form of patriotism that reflected the best of the American national project. It viewed American values and identity via collectivism and challenged the often dominant, more individualistic set of values that surrounded a patriotism that, to King, was automatic, reflexive, full of easy clichés and loyalties, but did not engage with its complexities and challenges. Speaking about a statement issued by the executive committee of Clergy and Laymen Concerned about Vietnam, King suggested "this is the first time in our nation's history that a significant number of its religious leaders have chosen to move beyond the prophesying of smooth patriotism to the high grounds of a firm dissent based upon the mandates of conscience and the reading of history." ${ }^{\text {ii }}$ Whilst King coins 
the term 'smooth patriotism' here, his entire life of activism, and much of the civil rights movement, centred around 'moving beyond' the easy patriotism that had become the consensus, to a position where he was able to combine his evolving political ideology and his spiritual convictions, and articulate his patriotic duty to speak out against what he considered socially, politically and spiritually wrong. King often made appeals to multiple appeals to multiple audiences using multiple tropes within even the same speech, and his encouragement of an alternative patriotism mutually reinforced his religious and moral appeals. King was very much aware of the history of tensions over competing conceptions of patriotism and this added power to what he was doing as he became able to situate his appeals to patriotism within a long context of discussions over national principles, values and founding documents. King had, in the past, evoked others who had spoken out in criticism of national policy in the past, including Lincoln and Thoreau, and so King tapped a rich seam of alternative patriotism that arced back to the early Republic. What made it particularly potent in the 1940s-60s was the way in which black activists powerfully fused alternative patriotism together with the civil rights movement to forge a powerful momentum, none more so than King himself.

4 One of the many reasons the movement succeeded in the mid-1950s until the mid-1960s was because it deployed this counter-hegemonic alternative patriotism to urge the nation, as King would later do with the Vietnam war, to rethink its collective interpretation - and application - of national values. The hegemonic 'smooth' patriotism identified by King had a number of core tenets that were in fact shared by his more collectivist patriotism, and key to his strategy's success was locating civil rights protest within the common ground that lay between characteristics and beliefs of 'smooth' patriotism and those of 'alternative' patriotism. This overlapping space housed the roots common to all patriotisms, whilst beyond lay ideological spheres in which patriotism became clear versions of ideological and political interpretation. The centre, though, was a site of constant ideological contest in order to gain ascendancy in what society at any given time would consider to be the consensus on a subject or how it would interpret an issue. Core beliefs were fiercely defended and mobilised to offer rationales for what was happening but, equally fiercely, politicians and activists tried to wrestle new or emerging issues into the public space of awareness, and present them as issues that were 'core', worthy of the nation's attention, and that their interpretation of these new issues would form the consensus on them. King and the movement generated enormous moral capital by focusing on new contexts surrounding education, desegregation of public facilities and the vote, and significantly shaped opinions on how patriotism and national values should react and accept these issues. The aim was to keep these issues as 'core' and ensure their exposure to the more collective interpretation of the national creed and, in the light of this, national public debate. King's rhetoric was extremely effective in doing this, and several historians have commented on his ability to affect people's interpretations of issues, a key aspect of alternative patriotism. As Thomas Jackson comments, "King was adept at stretching the terms of civic nationalism toward ideals of social democracy." "iii Taylor Branch observes that "his oratory gave King authority to reinterpret the core intuition of democratic justice. More than this his words, the timbre of his voice projected him across the racial divide and planted him as a new founding father." iv Able to assume this powerful role he was, as Vincent Harding claims, able to drive "toward the heart of the Constitution" in an attempt "to liberate the essential spirit of the document, 
especially as that spirit is represented in the Preamble" and to release the more collectivist impulses by moral suasion. ${ }^{v}$ Whilst King has become synonymous with 'patriotism', references to his associations with it often fail to acknowledge the differential interpretations of the American creed revealed and utilised, as well as King's mobilisation of a particular patriotism that was fused with his faith and strategically linked to a tradition of counter-hegemonic patriotic protest. For a time, alternative patriotism forged an irresistably strong momentum, and set alarm bells ringing for smooth patriots who strove to maintain individualistic interpretations (and consensus) at the 'core' of national ideological space. Crucially, as Michael Eric Dyson suggests, it was "on the rhetorical battleground of American public ideology" that "King wrested from them (segregationists, and equally the power structure) the prerogative of describing and defining what is authentically American." "vi This power to apply a more collectivist reading of the American creed to issues and win over support in the process was at the heart of alternative patriotism's success up to 1965.

5 As academic Harold Cruse noted, the U.S. "idealises the rights of the individual above everything else" and since aspects of alternative patriotism overlapped with individualistic sacred cows of the absolute right to vote, freedom of choice and employment, it helped fashion its distinctive and stinging moral momentum. ${ }^{\text {vii }}$ Alternative patriotism forced space surrounding the idea of patriotism to be prized open and re-examined. It pulled the race relations into debatable space, depriving administrations of the monopoly over American values and allowed protesters to both claim a stake in the concept of patriotism and also a voice in redressing the way in which black Americans had been excluded from the national narrative.

Protests therefore worked within a (relatively small) nexus of shared values and took full advantage of the moral and national leverage this provided. Activists in the 1940s-60s successfully stressed the case that the right to vote, the right to equal schooling, were moral and national absolutes that were germane to all Americans regardless of their political inclinations. In addition to wrestling themes into contention, the issues the movement wanted to move into the middle were also converging there as a result of Cold War politics and the exposure of racism as America's soft underbelly to Soviet propaganda. Mary Dudziak, amongst others, has ably demonstrated how this national embarrassment impacted upon government efforts to address obvious examples of institutional racism. viii Black activists were themselves willing participants in this process, utilising patriotism as a form of pressure, highlighting the lag between American rhetoric and the reality of the black experience. From civil and labor rights activist A.Philip Randolph's cry of 'We Are Americans Too' during the March on Washington Movement in 1941 to the wartime 'Double V' campaign that fought for freedom from oppression at home as well as abroad, employing patriotism was a useful tool both practically and ideologically. ${ }^{\text {ix }}$ Damaging Soviet propaganda compelled the nation to (albeit temporarily) broaden the idea of patriotism to assimilate black demands and transmit them as constituent parts of the consensual middle. Thus civil rights efforts to manipulate the centre ground and Cold War responses mutually reinforced each other and allowed alternative patriotism, despite its long and often counter-hegemonic history, to define itself as a distinctive strategy in the 1950s-60s.

7 For example, this type of exploitation by black activists is noted by Scott Sandage who identifies the trend emerging in 1939 when Marian Anderson sang at the Lincoln 
Memorial as a result of being turned away from Constitution Hall by the Daughters of the American Revolution. "Tactically, the modern civil rights movement came of age" Sandage writes, because it was "the first black mass action to evoke laudatory national publicity and earn a positive place in American public memory (our sometimes collective, always political sense of our past)" obsessed with defining Americanism, activists successfully portrayed their adversary as un-American." And of course this was part of the tactic, the ability to publicly shame acts such as the DAR refusal, or Bull Connor's violent response to protests in Birmingham in 1963, and in so doing validate their own actions as part of a refreshed and reinvigorated patriotism. By occupying the central overlapping space, garbed in a cloak of Americanism, there was a powerful shake-up that would last until the mid-1960s and what amounted to a backlash of smooth patriotism in Chicago.

Sandage argues that "black protesters refined a politics of memory at the Lincoln Memorial. Within the sacred, national space of the memorial, activists perfected a complex ritual of mass politics, one that exploited the ambiguities of cherished national values to circumvent opposition, unite coalitions, and legitimate black voices in national politics." $x i$ Over the ensuing years they also refined a politics of patriotism that made it possible to claim a place and a voice in re-shaping the conceptual and ideological borders of the middle. Sandage suggests that "protesters mobilised mainstream symbols to further alternative ends, to constitute (not just reflect) shared beliefs, and to open up spaces for social change... it was precisely the unrelenting nationalism that reigned from the 1930s to the 1960s that finally offered black activists a cultural language to speak to white America and to elicit support. The black church and Gandhian non-violence were not the movement's only wellsprings of unity and strength, the stories and values of American history were equally vital resources. The famous picket sign 'I AM A MAN', may have been morally compelling, but winning political and legal rights for blacks required a more focused message: I AM AN AMERICAN"'. This is the leverage that patriotism provided, and the further crystallisation of an alternative patriotism is something that A Philip Randolph developed, and King fully refined. .ii $^{\text {xi }}$

9 Through the intelligent use of this alternative patriotism, King and other activists assumed the power to weld activism and patriotism together to fashion nuances in national identity that assimilated counter-hegemonic ideas of patriotism into the consensus of the time. The inherent legitimacy and moral strength of alternative patriotism contributed to progress ranging from the local to the international. It worked to breathe life into the American creed and confront American society with its obvious shortcomings. The more successful it became in speaking to the more collectivist strains of the creed, the more it would inevitably conflict with the codes and meanings of the creed that had long been established by smooth patriotism. If protesters could legitimise themselves by positioning themselves within the area of overlapping values, the prevailing concept of an individualistic patriotism would be decentered, with substantial potential for societal change.

This is the philosophy and the strategy that King developed, carefully re-presenting key points of past racial conflict within this new socio-political context to revise public opinion. His use of alternative patriotism extended from his earliest sermons at Holt Street where he so powerfully harnessed the Constitution, to the end of his life when he spoke against Vietnam because, amongst other reasons, of his patriotism. 
11 His use of alternative patriotism, that built on the foundations laid by W.E.B DuBois and Frederick Douglass, forms one of the clearest, most coherent and distinct threads in his philosophy.

This tradition of critically analysing the fundamental nature of American society, identity and values has, as political scientist Michael C.Dawson argues, "been largely ignored, or occasionally ghettoised, because much of the study of the history of American political thought has often treated phenomena such as slavery, the Civil War, and race riots...as either non-events or anomalies in a history remarkably shaped by consensus. This tradition is also ignored because its major practitioners, such as DuBois and King, have more often than not been activists as well as intellectuals. The narrowness of this vision about 'where' democratic theory is created robs us of the insights to be gained from studying the work of those who thought deeply about many of the fundamental flaws of American democracy."xiii Dawson writes about King's counter-hegemonic use of patriotism, before and after Chicago, but not in the depth that might reveal the nuanced shifts in its character that Chicago and the housing crisis provide.

13 By employing the touchstones of American democracy and the symbols of the American creed, King and other alternative patriots held a tool that defied immediate and superficial criticism by shielding themselves with patriotism. Dyson argues that the choice posed by King to either live out the best of the American creed or else face moral stagnation was in fact the "primary impact" of King's life and career. ${ }^{\text {xiv }}$ Many civil rights activists reflected these transcendent, liberational qualities that approached something of a religious nature, a spiritual bond between the founding documents, protest, memory and collectivism. Throughout the chicago campaign, for example, there were silent vigils, witnesses and ritualistic returns to sites with contested meanings such as the Lincoln Memorial in Lincoln Park, and the stormy, redemptive marches through the white suburb of Cicero.

Alternative patriotism was a philosophy and a tactic that unpacked 'Americanism' and sought to employ some of the elements within to redefine America's ideological undercarriage, to confront concepts of belonging, identity, inclusion, and sought to redraw the idea of what was commonly accepted as American. In seeking to reverse the systematic exclusion of blacks from the nation's tenets, King embraced a patriotism that was not only more collective, but believed it to be truer to the original inspiration, and one that made a moral case for the widespread adoption of this interpretation of the American creed. King's Dream speech in Washington DC, 1963, displays the positive faith in the country's promise, proclaiming that his dream was one "deeply rooted in the American dream, that one day this nation will rise up and live out the true meaning of its creed - we hold these truths to be self-evident, that all men are created equal," vowing not to rest until it had been realised. ${ }^{\mathrm{x} v}$ As historian James Cone writes, "no persons tried to be American more than the integrationists. They have been called 'super Americans' and 'exaggerated Americans." still obscure the struggles within the conception of 'American'; King strived specifically to have alternative patriotism confront the longstanding hegemonic 'smooth' patriotism.

It proved at the same time to be a limited, complicated and constantly shifting space. Whilst the movement had successfully pinned a range of issues in the public spotlight, and was powerfully persuading the nation to re-think its attitudes toward them, the 
move north to Chicago in the mid-60s encountered a set of factors that meant the ability, and indeed the will, to remain operating in this space deteriorated. The result was that proponents of smooth patriotism were ultimately able to re-colonise and reappropriate some of the ground they'd lost in defining patriotism.

In the 1950s and early 1960 s the civil rights movement had very effectively manoeuvred issues revolving around voting and schooling into the 'core' space. Of course, these issues were not new and had long histories of tension and struggle, but King and the movement re-presented them in the specific context of a country that was affected by an evolving black activism signified by efforts such as the war-time March on Washington Movement, an increasing awareness of brutal violence such as the lynching of Emmet Till, Cold War considerations of race, global de-colonisation campaigns, and Supreme Court decisions such as Brown that desegregated Southern schools. When King and the movement moved north to Chicago in 1966, the aim was to pull what they considered to be a similarly big 'universal' issue, into the same core position and have it recognised as a national and essential concern that would, affected by the momentum of alternative patriotism, lead to change. The issue was housing. It, too, was an issue that had long been a site of racial contestation, not least in Chicago itself, but the movement gambled that more progressive interpretations of issues had gathered strength and that the ideological framework of the time meant it was the best time to push for change.

Civil rights issues were made part of a national patriotic task to redress racial inequality. Opponents, however, were quick to recognise that the moral and strategic exploitation of patriotism to open up debates on issues had its limits and in the case of housing they worked successfully and relentlessly to recast it as a fundamentally private issue, and not one for federal intervention as King argued. They worked hard to present housing as an issue that exceeded the logical constitutional goals of the civil rights movement, and pushed the idea that it was encroaching on white civil rights and individual choice. Housing became the wall that alternative patriotism crashed into, a wall quickly buttressed by white backlash, and from that point forward King and the movement lost much of their ability to effectively challenge smooth patriotism. Issues became harder for them to cast as part of a 'civil rights movement', a term that increasingly appeared too narrow to include housing and the other issue that consumed King's later years, economic justice.

Chicago was the terrain in which the civil rights movement faced an ideological and patriotic counter-attack that saw one its own most effective weapons - 'alternative patriotism' - neutralised. The city acted as the pivot. When the movement operated within the overlapping patriotic spheres it was able to achieve some of its greatest successes as it brought a more collectivist sensibility into mainstream discourse and infused a more universal reading of patriotism. The movement struggled when its successes encouraged it to push the collectivist project too hard, confronted strong ideological opposition that revolved around the lynchpin of housing, and in many ways the battle was won by those who were able to associate the housing issue more persuasively with their ideology and concept of patriotism.

During the long Chicago campaign and thereafter, King and the movement ultimately retreated from directly contesting smooth patriotism. The strength of white backlash, the campaign to view housing as an individualistic issue, and the challenge of persuading the public that the civil rights movement was not only ongoing, but that it 
embraced a range of issues beyond what was perceived to be a narrow set of 'civil rights' presented a daunting challenge. Chicago saw King and focus instead on developing alternative patriotism so that it embraced broader social and economic rights. Nurturing the more universal, collective aspects of the ideology, and not restricted as much by the need to slug issues out ideologically in the overlapping centre, King and alternative patriotism sharpened the focus on the natural elements of its creed. This is evidenced most significantly by the 1968 multi-racial Poor People's Campaign that targeted poverty, unemployment, education for poor adults and a fair minimum wage. The attempt to expand the parameters of the overlapping patriotisms was replaced by activism outside of that core space, protest that operated within the sphere of alterative patriotism: still connected, but not so directly involved in the contestation of consensual patriotism. Indeed its counter-hegemonic character became enhanced, but would never win as many ideological converts as it had when central on the national stage.

This was a move to the clearer waters of alternative patriotism and away from the turbulent seas of patriotic overlap. This ideological shift had significant impacts on King's final years and contributed to three things: firstly, it helped give clarity, shape and encouragement to King's social democratic philosophies and underscored the move to an emphasis on mutli-racial issues such as poverty and human rights. Secondly, it informed his position on the Vietnam war and allows us to view his patriotic stance on the conflict as a clear progression and reflection of his defence of an America shaped by alternative patriotism (and, equally, his rejection of one shaped by smooth patriotism) Both these factors together reveal that King's movement from battling in the overlapping common ground to a clearer position within the sphere of alternative patriotism helps provide a framework for thinking further about his often debated move to radicalism over the same 1965-68 period and presents an ideological and philosophical constancy that is sometimes lost in the way the last three years of King's life are dealt with. Historiographically, with the amount of research on local and regional civil rights struggles in the south, activism in the north, the contribution of white activists and the interweaving of civil rights and Black Power, King has been somewhat de-centered in recent works, but there are still very significant things to say about the strategies and ideologies that King utilised in order to engage and mobilise the administration, the media, and the American public both white and black. ${ }^{\text {xvii }}$ Finally, when this move is considered in context it raises interesting links with the Black Power movement and can, similarly, contribute to the growing literature on reconceptualisations of protest into a broader Black Freedom Movement or, as historian Peniel Joseph argues should be called Black Power Studies. ${ }^{\text {viii }}$ Black Power activists often perceived of themselves as moving beyond civil rights in an attempt to realise essentially social, cultural and human rights. In short, alternative patriotism allows us to characterise King's - and much of the movement's - philosophy and tactics in a particular way. The epic struggle between alternative and smooth patriotism to define the nature of issues, to influence the conscience of a nation and its perception of 'rights', and the very notion of patriotism itself reached its peak in Chicago. Housing was the key issue that witnessed the head-on collision within the overlapping spheres of patriotism and was responsible for King's move to a more clearly defined left-ofcentre position. Housing was a slippery and complex issue that ended up, in the face of re-grouped opposition, being beyond the ability of King and alternative patriotism to cast as an essential national issue. Chicago and housing pushed King out of the 
overlapping sphere but it lured him out by offering the opportunity to develop philosophies that better addressed issues of poverty and militarism in the mid-late 1960s.

\section{Chicago, housing and the re-direction of alternative patriotism}

21 A confluence of factors in the mid-1960s brutally exposed the fact that the overlapping space of competing patriotisms was both extremely limited and the site of constant and fierce ideological struggle. The edges of the middle ground were under constant threat of being breached by smooth patriotism in an effort to destabilise the movement's tactics and re-appropriate issues into the fold of individualism. Any movement beyond the boundaries of overlap, and beyond degrees of change that had been shown to be sympathetic with commonly accepted ideas of national values, would starve activism of the oxygen that its presentation of patriotism was generating.

As the movement shifted to Chicago, alternative patriotism began to lose it moral sting. In the mid-late 1960s, various elites continued to accommodate, negotiate and manipulate in an effort to reclaim guardianship over the meanings of American creed and, at the same time, massage a civil rights backlash. Restoring their trusteeship of the creed's interpretation was achieved not least by promoting the notion that the system had, as Sales puts it, "adequate provision for the correction of all social problems" and that they had now been resolved. ${ }^{\text {xix }}$ Smooth patriotism stressed the concept of law and order, one of its ideological roots, and this fast became one of the various ways in which now 'unnecessary' civil rights protests would be attacked President Johnson himself reflected that law and order were nothing more than "code words for racism" "xx whilst David Farber argues that when Nixon later called for law and order, it was "the permissible way to say 'Get the niggers'." xxi Consensual and hegemonic patriotism was re-set, against which the collectivist aspirations of the movement could be impugned.

Chicago provides a lens to observe the way in which smooth patriotism re-appropriated patriotic common ground through the issue of housing and the presentation of the movement's successful 'end,' and how the movement's alternative patriotism increasingly moved to operate outside of this area of overlap that had, up to that point, provided them ideological shelter and support. The 'classic' movement 'ended' in 1965 because its successes were boxed in by proponents of smooth patriotism who presented the legislation as having also been a part of their credo. They subsequently moved to seal off the movement as having been successful and no longer necessary. Their definition of success and the attempted re-appropriation of popular patriotism meant that further movement activism would be classed as many things: unpatriotic, unnecessary, impatient, dissenting, ungrateful, and not, somehow, a part of the civil rights movement any more. These charges had always been levelled at the movement but alternative patriotism had afforded them some protection. Working with the idea of the movement's 'closure', couple with the way in which housing became a rallying cry for smooth patriots and individualism, the charges cut more keenly.

The movement's relocation from the south to Chicago in 1966 was an effort to truly nationalise the movement, and activists waded through white backlash, urban racial violence that had started in the Watts district of Los Angeles the previous year and 
quickly spread, and what A.Philip Randolph had perceptively called the "crisis of victory'. Their challenge was not only to demonstrate to America that there was an ongoing need for the movement, but to ensure that further campaigns such as housing should be pulled into the same overlap as previous issues and be similarly perceived through the frame of alternative patriotism. King and the movement tried to imbue housing with the same kind of unambiguous compulsion based on national values as the right to vote or the right to a fair and equal education. To many activists the housing issue in Chicago should have been, fundamentally, in the intersection of patriotisms as they perceived it to be an issue of national and public concern, and that there should be federal intervention to ensure that housing was fair and open so that people should be free and able to move to where they chose. There should not be, moreover, segregated housing that helped sustain systems of institutional racism through both the housing itself and through the knock-on effect of neighbourhood schooling.

But alternative and smooth patriotism were often additionally separated by interpretations of issues being either in the private or public realm (frequently to do with positions on the notion of federal responsibility) The overlap between both 'sides' meant that, albeit somewhat reluctantly, basic civil and constitutional rights including the right to vote had been granted to the civil rights movement via landmark legislation as it was also a touchstone of smooth patriotism. However, the limitations of overlap were revealed when King and the Chicago campaign began to push at its boundaries when they mounted campaigns to de-segregate housing. As a result, they ran headlong into very substantial white ethnic opposition anchored to the 'smooth' patriotism of individualism and privacy. Whole communities mobilised to ensure that housing was a matter of individual and private choice. This mobilisation drew further strength from meshing with other forces. Firstly, it reflected a broader white backlash that believed the movement was now 'over' and that with 'a level playing field' opportunities were available to individuals to take advantage of. Further gains would be down to these individuals and would not be given further to a group; this was a clear indication of smooth patriotism reasserting itself. Secondly, it merged with (which itself bled into the previous point) what historian George Lipsitz terms the 'possessive investment in whiteness'. "Especially since the passage of the 1964 and 1965 Civil Rights Acts" he suggests, "the dominant discourse in our society argues that the problems facing communities of color no longer stem primarily from discrimination but from the characteristics of those communities themselves...a perverse sense of group identity and group entitlement that stands in the way of individual achievement and advancement." xxii Lipsitz suggests that whiteness needs to be seen as "an organizing principle in social and cultural relations" and that social structures have been historically established so as to protect an investment in whiteness. xxiii The fierce resistance amongst white ethnic groups to housing desegregation also represents their commitment to 'buying in' to whiteness and the benefits that accompanied this. The two together - individualism and whiteness - proved to be a potent force in the reacendancy of smooth patriotism.

In the post-depression years Chicago had forged a number of ways of protecting housing segregation but in the fifteen years after World War II the city "witnessed the renewal of massive black migration to Chicago and the overflowing of black population from established areas of residence grown too small, too old, and too decayed to hold old settlers and newcomers alike." ${ }^{\text {xxiv }}$ The white reaction to the idea of racially 
changing residential areas and restrictive covenants that attempted to racially engineer the make-up of neighbourhoods was supplemented by varying levels of violence. "Northern whites especially succeeded in preserving racially exclusive neighborhoods during the 1940s and 1950s through mob actions that went largely unpunished by law enforcement authorities." ${ }^{x x v}$ Opposition congealed to become part of the broader mid-60s white backlash that resisted further black progress but also coopted elements of the movement's philosophy to do so. Having so successfully articulated a movement for black empowerment, rights and self-determination, many northern whites (usually white ethnic groups) sought to utilise the same language to push for their own civil rights, which ran from the right to determine what kind of neighbourhood they wanted to live in to the schools that their children attended (which became a particular issue, for example, in Boston in the early 1970s with the imposition of busing in order to desegregate city schools). Whilst black activists had employed a 'rights' discourse in the context of pushing for greater collectivism, whites used it to shore up individualism.

Many urban whites saw housing sitting squarely within the realms of individual and private rights: the right to choose and maintain 'neighbourhoods'. This outlook was built upon racially exclusionist suppositions that had become so embedded as to become norms that revolved around issues of white identity. Housing pushed up, very rapidly, into issues of the right to private property, the right of the individual, and indeed a collection of like-minded individuals, to define the nature of that property and neighbourhood without it being jeopardised by interventionist public policy. Ronald Formisano's study of the Boston busing crisis reveals strong similarities between the white ethnic neighbourhoods of the two cities that felt their hard-won social norms and status were being threatened: "antibusing expressed rampant citizen alienation from impersonal government, drawing on an ingrained, deeply felt sense of injustice, unfairness, and deprivation of rights." What he termed "reactionary populism" clearly manifested itself in Chicago's suburbs. ${ }^{\text {xxvi }}$ Work by historian Thomas Sugrue sheds further light on the enormous scale and depth of white resistance across the north, and adds weight not just to Lipsitz's framing of a possessive investment in whiteness but to the reassertion of smooth patriotism. .xvii $^{\text {. }}$

Whilst there was some scope for housing to sit in the common ground between the two philosophies of patriotism it was an enormously divisive subject, sitting at the very borders of the core space, bleeding into nakedly partisan ideologies beyond. The impact was two-fold. Firstly, housing in Chicago encouraged King's drift toward a more open embrace of 'alternative patriotism' and much has been made of the way in which the northern campaign and the kind of virulent resistance that he encountered affected King ideologically. His experiences with extreme poverty, polarity of wealth, slums and institutional racism, deeply affected the way in which he and many other activists began to interpret the issues. This mapped the movement more exclusively into the area of 'alternative patriotism' wherein simple reform of society through patriotic and moral suasion was no longer sufficient, it required a much more fundamental shift in the way in which national values were perceived. The movement was drawn to this more collectivist interpretation of the American creed that sought to embrace an increasingly social and communal reading of patriotism, as evidenced in the comments King made about structural inequality and poverty whilst in the city, and ultimately in the Poor People's Campaign. It was thus a pull and push dynamic with forces pushing King out of the common ground and reasserting smooth patriotism whilst the 
situations that the movement confronted in Chicago pulled his underpinning philosophy much more firmly to the broader spaces of alternative patriotism. This arc toward the left, with a narrative based on the engagement between King, the movement, and the nation, with ideas of patriotism helps contribute to the discussions over King's move to 'radicalism' from 1965 to his death in 1968.

Secondly, as one of the major post-1965 civil rights issues, housing ran aground on the rocks of 'smooth patriotism', leaving the civil rights movement faltering in the city and nationwide. To many white ethnic communities and many white Americans more generally, the granting of rights to blacks only went as far as, crucially, the limited overlap between patriotisms. To some it had been a reluctant process, recognising that their own patriotism required it in order not to invalidate itself. As soon as an issue such as housing appeared, that was more open to ideological contest, it signalled the end of an era of incredible success for the civil rights movement that had gained so much through the use of patriotic reinterpretations.

\section{The re-appropriation of patriotism: the housing campaign in Chicago}

"My husband and I were both of the opinion when the Civil Rights law was passed that everyone in this country had a right to whatever the country had to offer, by hard work as our parents did...they did not demand anything, they worked for what they had." xxviii One of the hundreds of letters that Senator Paul Douglas (Democrat, with a liberal record) received over the summer of 1966 in the wake of the civil rights open-housing marches, it reveals the crystallisation of much popular sentiment surrounding the Civil Rights Movement, and captures the state of flux characterising the movement over 1965-66 in a snapshot. The city became the stage upon which the struggle over defining the consensual national patriotism played out.

31 The danger lurking within the alternative patriotism employed by the movement was that because the right to vote and the other civil rights attained were universally desired through the overlap with smooth patriotism, this ideological 'common ground' potentially disguised its net effectiveness and ability to push more progressive agendas. In other words, had the movement's success up to this point only been because they exploited overlapping values so that efforts to move beyond this shared area of patriotism would immediately result in a significant decline in support? Or had the movement succeeded in somehow reshaping and stretching popular concepts of patriotism so that further forays into social justice would be more acceptable to the nation and further protest would be viable? After voting rights legislation in 1965, the movement's task was to test this, seeking to transform further issues, such as fair housing, into ones that compelled similar reconsiderations of their place within the American tradition.

The CCCO (Coordinating Council of Community Organizations) had for years been campaigning around de facto segregation in the city revolving around education, housing and employment. ${ }^{\text {xix }}$ With the arrival of Martin Luther King, Jr., the newly formed Chicago Freedom Movement focused its efforts on fair and open housing, and sought, as King put it, to "eradicate a vicious system which seeks to further colonize thousands of Negroes within a slum environment." ${ }_{x x x}$ However, protests aimed at fair housing were quickly promoted by the city and many white ethnic communities as 
demands that went far above and beyond the levels of equal opportunity accorded to blacks via legislation in the previous years. They were certainly not demands that were constitutionally 'protected' and justified.

Southern Christian Leadership Conference strategist James Bevel spent much of 1965 in Chicago laying the groundwork ahead of King's arrival and the start of the 1966 campaign. During a series of workshop meetings with the West Side Organisation in the city in April 1965 a perceptive Bevel approached the subject of open housing: "ghetto housing is created by the Real Estate dealers, on purpose, and your job is to expose them. They had scared...the white folks, telling them if Negroes move in here the trees will die...but these are the cats who are most vulnerable to attack because this is the one thing everyone can see and understand...you don't even need to philosophise about housing in Chicago...you don't need to argue about that..." Clearly he hopes that housing was another issue where rights, wrongs and patriotic- Constitutional compulsion are clear, but doubts are expressed immediately afterwards when he acknowledged the difference in context: "Should a man have the right to live in a decent house? Now when that question is raised sufficiently I'll tell you what's going to happen - all these good white folks are going to say 'that's a communist movement'...I know my white folks, they will never let you down." Bevel's most telling comment followed, "then they're going to say 'Now I can understand the right to vote but the Constitution doesn't say that they have the right to live in a house...you'll hear 'they've (gone) too far now." ${ }^{x x i}$ This observation is absolutely key. Over this pivotal 1965-66 period, King reached a similar conclusion when he admitted that "the Constitution assured the right to vote, but there is no such assurance of the right to adequate housing." "xxxii The fears of both Bevel and King were realised during the 1966 campaign as resentful and hostile reactions to a summer of open-housing marches and the idea of fair housing ordinances spread.

With the disappointment over housing, this search for an issue that could be spotlighted in the common ground that would defy opposition continued. In January 1968 King reflected upon the deep frustrations surrounding the elusiveness of such an issue over the previous two years: "Let's find something that is so possible, so achievable, so pure, so simple that even the backlash can't do much to deny it... and yet something so non-token and so basic to life that even the black nationalists can't disagree with it." xxxiii Open housing had been the hope but attempts to wrestle the issue into this area of shared patriotism not only didn't bear fruit but it proved the terrain in which smooth patriotism would reassert itself.

The civil rights movement fell victim to the weight and power of the individualism championed within the hegemonic 'smooth' patriotism. Housing was not seen through the lens of 'everyone should have the right to good housing, an end to housing segregation and disparity', but rather through the lens of 'individuals should have the right to live wherever they want, to take advantage of the opportunities that they had been given in order to secure a home in a neighbourhood of their personal choice'. There was some success: after attempts at housing legislation collapsed in 1966 after a Senate filibuster, stalled in 1967, a civil rights bill finally passed as the Fair Housing Act in 1968. Pushed through in the wake of King's assassination in April 1968 the act demonstrated support in principle but it lacked strong enforcement mechanisms and didn't apply to mortgage lending. 

freedoms and defended the rights of "homeowners in a 'free society' to discriminate against Negroes if they chose" "xxxiv Interpreted in this way, the freedom to live wherever they chose allowed racism and white identity claims to coincide and build a formidable ideological barrier.

the common, core space and led to one version of patriotism now firmly squared up against another, each tapping into interpretations of the American tradition in order to validate their reading of the open housing issue. This confrontation of patriotisms and the rapid re-ascendance of smooth patriotism would, in addition to the reaction over housing, colour King's reactions to Vietnam. As people from all sides began to label his opposition to the war as mistaken and unpatriotic, King was left to defend himself as an alternative patriot struggling to save the soul of America. He argued that his dissent (alternative patriotism) should not be confused with disloyalty (not being loyal to a consensual smooth patriotism). As the struggle moved further and further from the shared common ground it exposed an ever more obvious clash of competing interpretations of American patriotism, values and identity.

Alternative patriotism was battling individualistic patriotism head-on and Bevel's insights echo through the comments of white residents in areas affected by the marches against residential segregation. These constantly refer to money, individual rights and assertions that consider housing to be far from the universal issue activists wanted it to be. Housing was perceived as both a reflection and result of the individualistic myth of working hard and owning property, something to be worked for within the framework of the consensual smooth patriotism. Individualism and property rights were intimately linked to the mythic vision of laissez-faire capitalism: blacks had ostensibly been given everything that was necessary with which to climb the same ladder of opportunity to actualise the American Dream, and if they did not now do so then it was deemed to be their own fault. This was an aspect of the 'crisis of victory' and as a further letter pleaded, "The Negro has equality, please do not take this same privilege away from the white people." ${ }^{\text {xxx }}$ Another summer of 1966 letter to Senator Douglas read "They think (civil rights activists) that demonstrating will get them anything they want - we had to work for what we got, let them do the same and maybe they'll be too tired to demonstrate. We feel that all open-occupancy laws are an infringement on our rights of property ownership." ${ }^{\text {xxxi }}$ A citizen's group similarly wrote that "we white people have taken a lot from the Negro. We have been patient and now feel ourselves pushed up against a wall by groups that feel it is their God-given right to have our property. We have worked hard and saved to get what we now own. Because we do work hard and wish to maintain our property are we to be denied the right to dispose of our property as we see fit? Is the ultimate aim the same as the Soviet Union when all property was collectivised...all this civil rights legislation is unAmerican."xxxvii Another wrote to Douglas imploring him to move to repeal the Civil Rights Act of 1964, providing a clear definition of smooth patriotism in the process, as the recent legislation would "rob a great many Americans of their rights to property, individual liberty, freedom of choice, and enterprise." xxxviii

For many white Americans, the Civil Rights Movement was complete and equality had been achieved. Greg Moses observes that "white people were happy to believe that the whole thing was finally over." ${ }^{\text {xxix }}$ Alternative patriotism was now violating what had quickly become the again-popular hegemonic patriotism, threatening status forged 
from the individualistic American Dream. "What do they want" asked another constituent, "everything dished out on a silver platter? Let them try to help themselves instead of giving them everything. We had to get everything the hard way, working very hard" xl Another pointed out that "Don't you think it's time to have Dr Martin Luther King and other negro leaders start preaching that they should go to work the same as white folks do, if they wish to improve their lot, instead of continuing to promise them more and more in all their talks." $x$ li

Eugene Kennedy writes that white ethnic communities "had been taught to work hard as well as to accept the inevitable unfairness and tragedy of existence; nobody, as they saw it, had given them, in their struggles as immigrant groups... an easy hand up out of their simple and often quite poor lives; they had come to value property as a sign of their achievement in their individual identity." $x$ lii Colburn and Pozzetta refer to this dominant smooth patriotism as the "bootstraps interpretation of the past, a view that focused on the group's ability to succeed based on their immigrant work ethic, sacrifice, family and loyalty." "liii Likewise, James Ralph writes that integration "threatened more than... financial security. It endangered their turf, their community, the place they called home... the possibility of black neighbors also imperiled Southwest Siders' own sense of their identity. Residence in a safe and stable all-white community... was a principal badge of their social achievement." ${ }^{\text {xliv }}$ It was perceived that protesters not only threatened status and identity but that they were 'cheating' the American 'tradition', not playing by the rules. In 'Sweet Land of Liberty' Thomas Sugrue observes that "suburbia represented the merger of identity and interest. Group membership - race - shaped where you lived and your self-perception. Whites saw their neighborhoods as the antithesis of the black ghetto" and "in a society that emphasized housing and real estate as a matter of free choice and explained the movement to suburbia as the consequence of hard work, the common-sensical explanations of racial inequality emphasized individual success and individual failure."xlv

Civil rights attorney Charles Morgan, living in Chicago, reasoned that "when civil grief began to hit the north in the pocket book and not only the conscience, southerners realized there would not soon be a national consensus on so universally touchy issue as fair-housing. We in the Chicago suburbs, are seeing these strange things happen today... liberal politicians turn their backs on the problem at election time..." "xlvi Martin Luther King, Jr. predicted that many of his former supporters would "fall by the wayside as the movement presses against financial privilege." "xvii Matters that encroached on personal economics, property and neighbourhoods were the hot-button issues of smooth patriotism. King attempted to link the private sphere with the public, pointing out that in the South, whites had not wanted to eat at the same lunch counters as African Americans or that blacks have equal access to public accommodations, but "this did not stop the nation from having its conscience so aroused.... now I think the same thing must happen in housing." ${ }^{\text {xlviii }}$ This quote perfectly captures the workings and the strategic aims of alternative patriotism and of the overlapping centre space, but the absolute difference with housing was that property and status were regarded as symbols and prizes attained through consensual smooth patriotism. Not only were these areas thus firmly within a perceived private sphere but they were, to a significant degree, maintained as such by successive administrations that were either naturally opposed to fair housing or else too wary of challenging housing segregation. There was thus an almost irresistibly strong resistance to the attempts of protesters to haul 
housing into the territory of overlapping patriotisms. Ralph hits upon it in the epilogue of Northern Protest when he writes that "even though fair housing was a plea for equal treatment (just as the cry for access to public accommodations and for the right vote had been), whites everywhere dismissed it as an illegitimate demand that threatened their right to basic, private decisions about the disposal of their property and, even more menacingly, threatened the quality of their neighborhoods." xlix

Anger simmered and the swiftly evolving backlash against civil rights demonstrated the very limited space in which it could operate successfully. The strength of smooth patriotism was encouraged by resentment. The virulence of white ethnic opposition meant that Mayor Daley did not want to alienate their support, and the strength of protest led him to essentially trade in much of his support from black communities in order to secure the loyalty of the white ethnic vote. As Taylor Branch reflects, "the mayor moved decisively to shore up the white ethnic wards, relegating integration to a charitable zone at the margin of politics."

One of the groups that attempted to exploit white ethnic opposition to the Civil Rights Movement in Chicago was Operation Crescent. The organisation's leader, Thomas Sutton, allied himself with white home-owners groups such as the Concerned Citizens of Cicero (CCC), and spoke out for individual rights and the protection of property. He also "helped to incite the violence by racist whites that greeted the open-housing marches in Chicago... 'Operation Crescent'... boasted that it provided its members with 'battle kits' to combat civil rights demonstrators." li

Sutton announced in time that he sought the Republican nomination for governor, and in his pre-election literature revealed Crescent was not only involved in keeping blacks out of 'white' areas, but he pledged to grant tax credit aid to parents not wishing to send their children to mixed race schools, promised to work for the elimination of Human Relations Commissions in state and city administrations, and lent support to the controversial Roman Catholic priest Francis X. Lawlor in a bid to install him to the Chicago archdiocese - Lawlor was himself involved in organising block clubs to 'hold back' the spreading ghetto and became something of a local folk hero for many whites. Finally, in a statement that reflected the extreme entrenchment of smooth patriotism and its association with personal mobility and status, Sutton pledged to fight openhousing legislation claiming that "the preservation of individual freedom and dignity for all property owners" was paramount. lii

Successive administrations had in a sense racialized consensual smooth patriotism in order that predominantly white ethnic groups could associate themselves with, and participate in, the promise of the American dream. This 'buy-in' resulted in a situation in which blacks were resented for having been allowed accelerated entry to the dream, something that was a violation of their own hard-won acceptance into the American system and an affront to the loyalties invested in what they had achieve. It was articulated in its most extreme sense by people such as Sutton but more generally manifested itself through the large numbers of relatively moderate home-owner groups that were established in white ethnic suburbs. This community sentiment was very much characterised by the individualistic, work-competitive, status-achieving patriotism so vulnerable to agitation in the face of perceived threats to their beliefs and identification with America: "It is my opinion" wrote another constituent, "that the entire so-called 'civil rights' legislation should be reappraised. Money and laws will not automatically instill responsibility, honor, duty or achievement.... I think Negroes, as a 
body, will be accepted generally when and if they follow the example of the other ethnic groups that have in the past been discriminated against. These groups worked hard, built their communities, religious institutions, hospitals, etc. through their thrift, example, education, and encouragement of their offspring to attain higher social status, they won general admiration and acceptance. This all was accomplished without any government hand-out..." liii

These feelings in 1966 and beyond had been fuelled in no small part by the Civil Rights Bill of 1964, which accounts for much of the subsequent outrage. With the racialization of the American Dream and the loyalty to an individualism that was a part of the social fabric, the enactment of the Civil Rights Bill was for many something approaching a betrayal. Significantly, a great number of letters sent to Senator Douglas complained not about the specific grant of civil rights to African-Americans - an implicit recognition and acknowledgement of rights in the overlapping area - but about the intervention in personal and individual matters. The administration was itself perceived as tampering with the ingrained American patriotism and the idea that further civil rights legislation was being discussed with a specific focus on housing was unthinkable: "We have no dispute with the Negro populace in this country and agree with them that proper civil rights legislation is in order" wrote one Chicago resident, "but we do dispute...the present bill....it is an outright and a deliberate attempt on the part of the present administration for wholesale federal intervention in our homes, schools, jobs, everything it seems, with the one possible exception of religion." liv "This bill" wrote another, "is nothing more than a bill designed to deprive American citizens of their rights as perceived in the Constitution." "lv One resident wrote that "we believe in democracy...." but that "this legislation makes a mockery of the Constitution by destroying its guarantee of the rights of the individual as we have known them throughout the years."

The railing against what another Chicagoan termed the "increase of federal power over our private lives" is most explicitly presented in a letter and petition dated March 28, 1964. Those who signed expressed a belief in "our right to build or buy our home without federal interference. Our right to occupy, rent or sell our home without federal interference... and "our right to personal choice and liberty under the law and not federal supervision of individual homes, schools and businesses."

The ideological grounding for anti-civil rights protests in 1966 gathered pace. Participation in, and a vocal faith in, individualistic smooth patriotism had become so firm as to become semi-autonomous, and it revealed the potential for severe political repercussions. Their belief that the Civil Rights Movement had gone too far was reflected in the Senate as Johnson's 1966 fair-housing bill was debated. Senate minority leader Everett Dirksen (who effectively held the key to the outcome) referred to Chicago specifically in his speech and as civil rights protesters in the city were losing their struggle over the use of patriotism to interpret issues and make the housing issue a seemingly legitimate one, Dirksen claimed that going into white areas in the city was "calculated harassment. It's a species of intimidation. It's like saying they're either gonna do this or else." The bill of 1966 was not passed and it died in the early autumn (September 19) as individual rights and civil rights that were embedded within smooth patriotism were depicted as being under threat. Indeed, the House of Representatives passed a bill that acknowledged the 'right' of individuals to discriminate in selling their 
homes. Smooth patriotism had reaffirmed itself as alternative patriotism found itself unable to create a morally, or Constitutionally, compelling case for open housing.

Alternative patriotism was rapidly cast as positively unpatriotic, a process that would be doubled up as King himself was vilified over his comments on Vietnam in the aftermath of the Riverside Church speech in April 1967. The New York Times ran an article entitled 'Dr.King's Error' in which his comments were labelled as "wasteful and self-defeating." For King, one of the strongest links between civil rights and peace was provided by alternative patriotism, characterised by a shared drive to save the soul of America through a fuller realisation of its more collective ideals. When the Times suggested that "a fusing of two public problems that are distinct and separate could very well be disastrous for both causes" and quoted the NAACP in calling it a "Serious Tactical Mistake' to Merge Rights and Peace Drives," the philosophical glue of alternative patriotism was overlooked and misunderstood despite King's protestations. ${ }^{\text {lvii }}$ His comments on Vietnam were entirely consistent with an alternative patriotism that was widening its boundaries, but the widespread and fierce response to King's anti-war position helped push him further away from the centre.

In short, King's comments contributed to an overarching re-calibration of patriotism at the national level that saw the alternative patriotism harnessed by civil rights pushed to the very edges of the central core and beyond what could be refashioned as consensus. Immensely powerful until 1965, the strategic use of alternative patriotism as a result weakened whilst proponents of smooth patriotism regained their grip on 'consensual', hegemonic patriotism and the ability to present the unfolding narrative on their own terms.

51 This returns to the question of whether alternative patriotism had been successful in its own collective ambitions or whether it had succeeded only in exposing a technical 'gap' within the consensual system; that instead of making gains in altering perceptions of American patriotism and ideals at a fundamental level, it had in fact merely exposed voting and basic civil rights as clauses that had to be honoured because they also sat within the realm of smooth patriotism and its own set of civil rights. When it then attempted to enlarge the area of overlap any sense of agreement and accommodation immediately dissipated. This should certainly be seen as a factor when examining the dramatic mid-1960s shift from government action supporting civil rights legislation to 'backlash' and the administration retreating from further strong commitments.

Finally, the ideological and conceptual confrontations that offer so much insight into the nature of King's philosophy and movement strategy had their own interactions with the emerging Black Power movement in the mid-1960s. The thread of alternative patriotism can contribute to the growing literature on what Peniel Joseph argues should be called Black Power Studies. Since the 'classic' or "heroic" civil rights movement is generally (within American society) accepted as taking place 1955-1965, "such a characterization," he points out, "removes from the spotlight... those that went beyond the call for civil rights to advocate radical systemic social and political change" and "such a description creates a situation in which the BPM (Black Power Movement) can be conveniently blamed for the demise of the Civil Rights Movement, rather than being viewed as an alternative to the ineffectiveness of civil rights demands in critical areas of American life." lix Joseph and other, such as Komozi Woodard, Timothy Tyson, Robert Self and Jeanne Theoharis, have thrown light on the 'long Black Power Movement' that substantially challenges the conventional and restricted narrative 
'blocks' in which the two movements back onto each other and are largely seen as "two fundamentally dichotomous eras." occupying distinct branches, share roots in the same historical family tree," they overlapped and intertwined to more accurately recast "post-war African American history as an almost half-century long black freedom movement that - although highlighted by distinct strains, political differences, and conflicts - featured connections and continuities previously missed." "xi Many within black communities especially in the north - had grown critical and weary of a civil rights philosophy that placed so much emphasis on trying to make real the promises of the American Dream, and wearied of alternative patriotism's appeal to the nation to interpret issues in a broader and more inclusive way. The shift from civil rights to Black Power was, amongst other things, a reflection of the disillusionment with both the tactics and response. Melvin Leimann, for example, suggests that at a general and national level, the widespread adoption of, or sympathy with, black nationalism was a result of disillusionment with access to American values, what he describes as a defensive action $^{\text {lxii }}$ and the growing visibility of the Black Power movement can be linked to a retreat from (any kind of) patriotism being used as an ideological strategy. Black Power advocates believed that American society and values should be fundamentally altered rather than simply reformed, and this is not dissimilar to the position that alternative patriotism and King had reached.

This also raises important questions about King's trajectory after 1965 and his relationship with alternative patriotism itself, which became tortuous to the point that King "became convinced of the nation's recalcitrance, "believing that "racism was entrenched within the American psyche as well as American social, political, and economic structures." Strategically, alternative patriotism was hitting the wall of private and individual rights orchestrated by smooth patriotism, and philosophically, King became increasingly disillusioned. In terms of the American creed, Michael Dawson argues that not only did King come to have "deep doubts about whether white Americans in fact supported that tradition, but also that he began to harbour deep doubts about the goodness of the tradition itself...certain aspects of King's thought

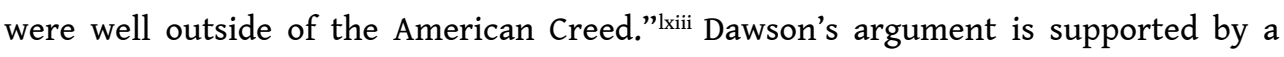
Malcolm X quote that he then applies with equal validity to King: in an address to SNCC workers in Selma, Alabama in 1965, Malcolm told them that "I disagree with nonviolence, but I respect the fact that you're on the front lines and you're down here suffering for a version of freedom larger than America's prepared to accept." ${ }^{x i v}$ King's disillusionment is seen in 1967 when he argued that "most whites...including many persons of goodwill... proceed from a premise that equality is a loose expression for improvement. White America is not even psychologically organised to close the gap essentially is seeks only to make is less painful and less obvious but in most respects to retain it." ${ }^{x v}$ The attempt to have alternative patriotism interpret housing as an issue in need of national attention was a project larger than America was prepared to accept.

Alternative patriotism as a characteristic of the national movement was fragmented beyond repair. An enduringly strong and resilient smooth patriotism that was largely responsible for provoking a white backlash, combined with the difficulty in raising further issues due to the rigidity of the space in which values overlapped, the narrowness of what was perceived as a civil rights agenda, and potentially the strategic limits of alternative patriotism itself (both in terms of maintaining support within black communities, particularly in the north, and whether its success had come only 
through exploiting smooth patriotisms own values). The confluence of factors ensured that the administration began rapidly to restore the familiarity of a more individualistic set of socio-political interpretations, and to re-appropriate the hegemonic position in terms of the consensus around American values.. Set against the backdrop of protesters' violation of personal space and somewhat ironically homeowners' own civil rights, the open-housing marches in Chicago proved to be the power structure's most useful vehicle for this re-appropriation.

There was now an insistent presentation of the period after civil rights legislation as a post-civil rights era, as a level playing field, that the quest for equality had been successfully concluded, and that the values of smooth patriotism had been partially responsible for the progress gained and the removal of the movement's raison d'etre. As Kent states, Nixon was "content to view it as completed history"|xvi This was the strategic 'trap' that alternative patriotism now sprung, and points to both its possible limitations as well as the well-oiled machinery of smooth patriotism.

The counter-offensive even attempted to place the Civil Rights Movement within the historical context of the individualistic American Dream and smooth patriotism, suggesting that white society believe the protesters had essentially been seeking an opportunity to participate in the system and that the legislation passed in 1964 and 1965 had ironed out the discrepancies. Any further protest was unnecessary as the system was now equitable in that everyone had the equal chance to work hard and better themselves. The moral sting was removed from the 'American Dilemma' as a more individualistic set of values was forwarded as being centrist, reasonable and at the heart of the meaning of American patriotism. Rather than the values of the more collectivist patriotism persuading the nation that more issues should be incontestably right, it was the individualistic one that had emerged triumphant, and the nation could believe itself (to its relief) to be functioning at a level that successfully carried out the implications made in the founding documents. In 1967, King perceived that there was a new phase of white resistance: "based on the cruel judgement that Negroes have come far enough, there is a strong mood to bring the civil rights movement to a halt or reduce it to a crawl. Negro demands that yesterday evoked admiration and support, today - to many - have become tiresome, unwarranted, and a disturbance to the enjoyment of their life."

57 As James Ralph writes on Chicago in Northern Protest, “Dr. Martin Luther King's Chicago campaign... failed to produce the moral response of earlier campaigns in Montgomery, Birmingham and Selma." ${ }^{\text {lxvii }}$ The city machine of Mayor Daley had reacted in a way that legitimised the 'bootstraps patriotism' of many white ethnics and discredited civil rights strategy. They had been able, through their ideological counter-offensive, to reappropriate the common ground of patriotic meaning, pose as conservers of a tradition which underlay the nation's values, casting civil rights activism as increasingly radical and un-American. Attempts to present new issues as incontestably and morally centreground met a wall of solid social, cultural, racial and political resistance and the narrative of national values continued to be written in the language of smooth patriotism, grafting civil rights success onto its on-going presentation as consensus patriotism.

58 King's use of alternative patriotism continued after Chicago and as he moved forward he clutched strands of collectivism that he could now focus on without the compulsion to shoehorn them into a package that would be consensually acceptable. Disillusioned, 
he downplayed the struggle for a fulfilment of the creed, but his philosophies that had always been rooted in the politics of social democracy, support for economic justice, a fairer distribution of wealth, were able to fully flourish. His observations about the need for America to embark on a radical redistribution of wealth, for example, sprung directly from the values of alternative patriotism. As he largely moved from the central space of contesting the applications and interpretations of patriotism, the guardians of the individualistic smooth patriotism rapidly overran the ground he had vacated, painted him as a radical who now operated outside of the American patriotic consensus, and the mid-long term effects of which were, as Singh has noted, overwhelming.

Indeed, one of the reasons why there was such opposition to Martin Luther King Jr. day was that conservatives did not want to celebrate the later, collectivist patriotism of King as this would potentially distort the consensual grip they had on the nation's narratives. The day has, consequently, arguably fallen victim to the ascendancy of smooth patriotism and become a day that celebrates the patriotism that sat squarely in the common space between overlapping spheres. As a result, the Dream and the patriotism celebrated and remembered is one that can be claimed equally by both left and right. As Singh reflects, "King.... has become part of a mythic nationalist discourse that claims his antiracist imperatives as its own, even as it obscures his significantly more complex, worldly, and radical politics." "1xix

Without the shield of patriotism offered through overlapping values, King and the movement became increasingly vulnerable to charges of militancy, radicalism and unAmericanness. The struggle to persuade a nation that on-going protest was not only necessary but that it was part of a larger ideological movement to fashion a greater America, was increasingly difficult and was complicated by King's ambivalence about America. King's final campaign before his death, the Poor People's Campaign, was to support the poor "in a crusade to reform society in order to realize economic and social justice," which included not only poor blacks but all poor people living in America from Mexicans and American Indians to white Appalachians. ${ }^{\mathrm{lxx}}$ This is clearly evidence of alternative patriotism continuing to shape ongoing civil rights protest, but it did so in a post-Chicago landscape. The Chicago campaign had deeply wounded alternative patriotism and its ability to inspire change through the application of a more collective interpretation of the nation's creed. Chicago also exposed the limitations of the strategy as the changes that it now sought represented larger and ever more fundamental changes in the fabric of society and its values that reached well beyond the overlapping space it had previously operated in. The Poor People's Campaign fought the good fight, but again Malcolm X's words are apt as it was for a "version of freedom larger than America's prepared to accept." In early 1968, King told journalist David Halberstam that "For years I labored with the idea of reforming the existing institutions of society, a little change here, a little change there. Now I feel quite differently. I think you've got to have a reconstruction of the entire society, a revolution of values."1xxi No longer committed to stretching the overlapping space to accommodate issues, King worked to erase the borders altogether. 


\section{NOTES}

i. Martin Luther King, A Time to Break Silence, April 4, 1967. E.g. Martin Lither King, Jr. Research and Education Institute: https://kinginstitute.stanford.edu/king-papers/documents/beyondvietnam

ii. Ibid

iii. Thomas Jackson, From Civil Rights to Human Rights: Martin Luther King, Jr., and the Struggle for Economic Justice, University of Pennsylvania Press, 2006, p.81

iv. Cited in Larry Copeland, Pealing bells to mark 50 years since MLK's rousing 'Dream', USA Today, July 17, 2013

v. Vincent Harding, Wrestling Toward the Dawn: the Afro-American Freedom Movement and the Changing Constitution', Journal of American History, December 1987, p.720

vi. Michael Eric Dyson, Reflecting Black, Minnesota University Press, 1993, p.232

vii. Harold Cruse, The Crisis of the Black Intellectual, Allen, 1969, p.6

viii. See Mary Dudziak, Cold War Civil Rights: Race and the image of American democracy, Princeton University Press, 2000. There are numerous, excellent, studies on related themes, eg. Azza Salama Layton, International Politics and Civil Rights Policies in the United States, Cambridge University Press, 2000, Thomas Borstelmann, The Cold War and the Color Line: American race relations in the global area, Harvard University Press, 2001. In addition, recent scholarship has also thrown light on the impact of Cold War politics on the roots of Black Power: See Komozi Woodard, A Nation Within a Nation: Amiri Baraka and Black Power Politics, University of North Carolina Press, 1999, and Timothy Tyson, Radio Free Dixie: Robert F Williams and the roots of Black Power, University of North Carolina Press, 2001

ix. The Double V campaign, Victory Abroad and Victory at home was orchestrated by the Pittsburgh Courier, an African American newspaper, in 1942 and gained widespread traction.

x. Scott Sandage, A Marble House Divided: The Lincoln Memorial, the Civil Rights Movement, and the Politics of Memory, 1939-1963, Journal of American History, June 1993, p.136

xi. Ibid, p.136, p.136

xii. Ibid, p.138

xiii. Michael Dawson, Black Visions: The Roots of Contemporary African American Political Ideologies, University of Chicago, 2001, p.274

xiv. Dyson, Reflecting Black, p.231

xv. James M.Washington, I Have a Dream: Writings and Speeches that changed the world (HarperCollins, New York, 1992) p.103

xvi. James H.Cone, Martin \& Malcolm \& America: A Dream or a Nightmare, (Orbis, New York, 1992) p. 67

xvii. For example, particularly in the context of Chicago, Thomas Sugrue, The Origins of the Urban Crisis: Race and Inequality in Postwar Detroit, Princeton University Press, 2005, and Sweet Land of Liberty, Random House, 2009, Jeanne Theoharid, Komozi Woodard (eds) Freedom North: Black Freedom Struggle Outside the South 1940-1980, Palgrave Macmillan, 2003

xviii. Peniel E.Joseph (ed.), The Black Power Movement: Rethinking the Civil Rights-Black Power Era Routledge: New York, 2006

xix. William Sales, From Civil Rights to Human Liberation: Malcolm X and the Organisation of Afrto American Unity, South End Press, 1994, p.47

xx. Kenneth O’Reilly, Racial Matters: The FBI's Secret File on Black America, 1960-1972, Free Press, 1991, p.230

xxi. David Farber, Chicago '68, Chicago University Press, 1988, p.234

xxii. George Lipsitz, The Possessive Investment in Whiteness (Temple University Press, 1998) p.24 
xxiii. Ibid., p.1

xxiv. Arnold Hirsch, Making the Second Ghetto: Race and Housing in Chicago 1940-1960, University of Chicago Press, 1983, p.5

xxv. Lipsitz, Possessive, p.26

xxvi. Ronald P.Formisano, Boston Against Busing: Race, Class and Ethnicity in the 1960s and 1970s, University of North Carolina Press, 2004 ed., p.3

xxvii. See Thomas Sugrue, The Origins of the Urban Crisis: Race and Inequality in Postwar Detroit (Princeton University Press, 2005) and Sweet Land of Liberty (Random House, 2009)

xxviii. Letter dated August 5, 1966, Paul Douglas papers, Box 722, Chicago Historical Society

xxix. See Alan B.Anderson and George W.Pickering, Confronting the Color Line:The Broken Promise of the Civil Rights Movement in Chicago, University of Georgia Press, 2008; James Ralph, Northern Protest: Martin Luther King, Jr., Chicago, and the Civil Rights Movement, Harvard University Press, 1993; David Garrow, Bearing the Cross (Vintage, 1988)

xxx. King, Interview by Mr. Smith, 18 March 1966, MLKJP-GAMK. Stanford University King Project: http://mlk-kpp01.stanford.edu/index.php/encyclopedia/encyclopedia/ enc_chicago_campaign/

xxxi. James Bevel, April 3, 1965. Third workshop meeting with The Woodlawn Organization and the West Side Christian Parish, sponsored by the American Friends Services Committee, Bevel papers, University of Illinois at Chicago

xxxii. Cited in Washington, I Have A Dream, p.131

xxxiii. Jackson, From Civil Rights, p.363

xxxiv. Martin Gilens, Why Americans hate welfare: Race, Media, and the Politics of Antipoverty Policy, University of Chicago Press, 2009, p.126

xxxv. Letter to Douglas, dated November 1, 1966, Douglas papers, Box 722

xxxvi. Letter to Douglas, dated August 17, 1966, Douglas papers, Box 722

xxxvii. Marquette Park area group to Douglas, August 5, 1966, Douglas papers, Box 722

xxxviii. Letter to Douglas, Douglas papers, Box 722

xxxix. Greg Moses, Revolution of Conscience: Martin Luther King, Jr and the Philosophy of Nonviolence, Guilford, 1998, p.36

xl. Letter to Douglas, August 17, 1966 (different to above) Douglas papers, Box 722

xli. Letter to Douglas, July 1966, Douglas Papers Box 722

xlii. Eugene Kennedy, HIMSELF! (Viking 1978) p.196

xliii. David R.Colburn and George E.Pozzetta, 'Race, Ethnicity, and the Evolution of Political Legitimacy,' in David Farber (ed), The Sixties: From Memory to History, University of North Carolina, 1994, p.135

xliv. James Ralph, Northern Protest: Martin Luther King, Jr., Chicago and the Civil Rights Movement, Harvard University Press, 1993, p.125

xlv. Thomas J.Sugrue, Sweet Land of Liberty: The Forgotten Struggle for Civil Rights in the North, Random House, 2008, p.206

xlvi. Charles Morgan, Montclare-Leyden Herald, Chicago, March 15, 1967

xlvii. Cited in Moses, Revolution of Conscience, p.32

xlviii. NBC, Meet the Press, 21 August1966

xlix. Ralph, Northern, p.176; p.234

1. Taylor Branch, At Canaan's Edge: American in the King years 1965-1968, Simon and Schuster, 2007, p.550

li. Chicago Tribune, April 6, 1968

lii. Ibid

liii. Letter to Douglas 1966, Douglas papers, Box 722

liv. Letter to Douglas, March 19, 1964, Douglas papers, Box 717

lv. Letter to Douglas, April 6, 1964, Douglas papers 
lvi. Letter to Douglas, April 13, 1964, Douglas papers

lvii. Letter to Douglas on the "so-called" Civil Rights Bill, March 28, 1964, Douglas papers

lviii. New York Times, April 7, 1967, p.36 and New York Times April 11, 1967, p.1

lix. Peniel E.Joseph (ed.), The Black Power Movement: Rethinking the Civil Rights-Black Power Era, Routledge, 2006, p.3

1x. Joseph, Black Power, p.25. See also Komozi Woodard, A Nation Within a Nation: Amiri Baraka and Black Power Politics, University of North Carolina Press, 1999, Timothy Tyson, Radio Free Dixie: Robert F Williams and the roots of Black Power, University of North Carolina Press, 2001, Jeanne Theoharid, Komozi Woodard (eds) Freedom North: Black Freedom Struggle Outside the South 1940-1980, Palgrave Macmillan, 2003, Jeanne Theoharis, Komozi Woodard and Charles M.Payne (eds) Groundwork: Local Black Freedom Movements in America, New York University, 2005, Robert O.Self, American Babylon: Race and the Struggle for Postwar Oakland, Princeton University Press, 2003 lxi. Ibid, p4, p.25

lxii. Melvin Leimann, The Political Economy of Racism, Pluto, 1993, p.261

lxiii. Dawson, Black Visions, p.14

lxiv. Ibid, p.241

lxv. King, The Trumpet of Conscience, in James M.Washington (ed) A Testament of Hope: The Essential Writings and Speeches of Martin Luther King, Jr., Harper \& Row, 1986, p.560

lxvi. Noel Jacob Kent, 'To Polarize a Nation,' Crawford Young, ed., The Rising Tide of Cultural Pluralism, University of Wisconsin Press, 1993, p.60; p.62; p.61

lxvii. King, Where Do We Go From Here: Chaos or Community? Beacon Hill Press, 1967, pp11-12

lxviii. Ralph, Northern, p.189

lxix. Ibid

lxx. Jackson, From Civil Rights, p.332

1xxi. Cited in Peter Drier, Martin Luther King was a Radical, Not a Saint, Huffington Post, January 20, 2013

\section{INDEX}

Keywords: Martin Luther King 